\title{
Family Ownership Role in Strengthening the Relationship Between Intellectual Capital and Financial Performance: Research in High-Tech Firms in Indonesia and Philippines
}

\author{
Bima Cinintya Pratama \\ Universitas Muhammadiyah Purwokerto \\ BimaCinintyaPratama@ump.ac.id
}

\begin{abstract}
Intellectual Capital (IC) is important because firms in ASEAN needs a lot of competitive advantage, mainly from IC, in order to compete in the era of ASEAN Economics Community (AEC). This research investigates the positive relationship between intellectual capital and firm performance and examine the role of family ownership on the relationship between intellectual capital and firm performance. The data collected from annual report from high-tech industries and conducted on two ASEAN countries, namely Indonesia and Philippines. The final sample used in this research consists of a total of 264 observations. This research uses panel data regression model analysis, i.e. fixed effect regression and random effect regression. The results showed that intellectual capital has a positive effect on financial performance in Indonesia and Philippines. This result indicates that intellectual capital can give higher financial performance for the firms. On the other hand, the result cannot found the moderating role of family ownership on the relationship between IC and firm financial performance. It revealed that the alignment effect might not be applicable to all countries.
\end{abstract}

Keywords: Intellectual Capital, Family Ownership, Financial Performance.

\section{INTRODUCTION}

ASEAN economic community (AEC) will force regional economic integration between the members of ASEAN countries. This is challenging for the company in order to continue to survive for the sake of business continuity. According to Sawarjuwono and Kadir[1], in order to survive in accordance with the concept of going concern, companies must quickly change their strategy from labor-based business to knowledge based business. The paradigm will make companies to improve company ability in processing the resources they have to create corporate value as a competitive advantage. One of them is by increasing the company's intellectual capital. Intellectual capital in the company is a knowledge resource based on the employees, customers, processes, and technologies used by companies in value[2].

Resource-based theory (RBT) explains that intellectual capital (IC) is a resource that serves as the core of value creation and competitive advantage for firms[3]. The growth and sustainability of companies will depend on the development of the company resources, as explained by RBT perspectives. Thus, effective and efficient use of IC will encourage the company's ability to generate profit. Therefore, this research will examine the effect of IC on company's financial performance on high-tech companies in Indonesia and the Philippines.

Previous research by Pratama and Wibowo[4], has examined the role of family ownership in further explaining about the relationship between IC and financial performance of firms in Indonesia. Pratama and Wibowo[4] stated that the positive relationship between IC and the company's financial performance may be influenced by family ownership. Furthermore, research by Claessens et al.[5] and Carney and Child[6] proves that companies in East Asia, including ASEAN, are firms which ownership is concentrated predominantly on the family ownership. Therefore, this research will try to develop the research by Pratama and Wibowo[4] by further examining the role of family ownership in further explaining positive relationship between IC and financial performance of the company in Indonesia, plus another ASEAN country, namely the Philippines.

This research uses Value Added Intellectual Coefficient (VAIC) method developed by Pulic[7], [8] to measure IC by using a monetary measurement. Companies engaged in high-tech industries have been well known as companies that tend to rely on IC in their operations, so it is suitable for this research. This research uses panel data regression model (i.e. fixed effect and random effect regression). This research contributes to the literature of IC by developing the research from Pratama and Wibowo[4] by testing the role of family ownership in further explaining positive relationship between IC and financial performance of companies in Indonesia and Philippines, as representatives of ASEAN. 


\section{LITERATURE REVIEW}

\section{Resource-based Theory (RBT)}

RBT provides an important framework to explain and predict what can be an underlying for competitive advantage and firm performance[9]. In relation to this research, Resource Based Theory explains that companies, which have intellectual capital, will be able to create competitive advantage, so that it will improve the company's financial performance.

\section{Intellectual Capital and Firm Performance}

Resource-based theory (RBT) explains that intellectual capital (IC) is a resource that serves as the core of value creation and competitive advantage for firm[3]. It can be said that IC performs an important role in value creation and sustainable growth of the firm. From the RBT perspective, the firm ability to maintain asset resources that are valuable, rare and irreplaceable and also allocating and deploying these resources effectively is closely related to the creation of a sustainable competitive advantage[3]. Due to competitive advantage of intellectual capital, it is expected to increase sales and use of the company's resources efficiently and effectively which can make an increase in the company's profit. Based on above explanation, the hypotheses proposed in this research are as follows:

H1: Intellectual capital has positive effect on the firm financial performance of high-technology firms in Indonesia and Philippines.

\section{Intellectual Capital, Family Ownership, and Firm Performance}

Referring to the statement from Grant[10], IC won't have the capacity to give an ideal competitive advantage without proper organization and allocation of the resource. The firm ability to organize and manage resources nicely is one of the main requirements for the firm to create a competitive advantage from these resources, consistent with RBT. Shareholders of the firm is one of the most responsible for supervising the firm activities management, including the activities of managing IC[11].

Previous research from Claessens et al.[5] and Carney and Child[6] found that firms in East Asia, including ASEAN, are firms which ownership is concentrated predominantly on the family ownership. Consistent with the alignment effect on the family ownership of firm, Anderson and Reeb[12] showed that family firms are more efficient in terms of supervision and management of firm activity compared to firms that are widely held by public. Based on the explanations that have been described above, the hypotheses that can be proposed are as follows:

H2: Family ownership has a significant positive role in moderating the relationship between intellectual capital and financial performance of high-technology firms in Indonesia and Philippines.

\section{Sample}

\section{METHOD}

The sample in this research was obtained from firm's annual reports. The sample of this research are the firms engaged in high technology industries. This research conducted on two ASEAN countries namely Indonesia and Philippines. The type of industry that is considered as high-technology industry refers to the industrial classification based on the Standard Industrial Classification (SIC). Table 1 shows the final sample used and its distribution by country and industry.

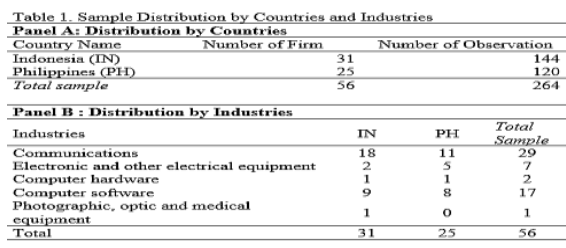

\section{Variables}

Independent Variable

Intellectual Capital (VAIC). IC measured using VAIC which was developed by Pulic[7], [8]. VAIC measured by the following equation:

Where:

$$
V A I C_{t}=H C E_{t}+S C E_{t}+C E E_{t}
$$

VAIC $_{\mathbf{t}}=$ Value added intellectual coefficient at $\mathrm{t}$

$\mathbf{H C E}_{\mathbf{t}}=\mathrm{VA}_{\mathrm{t}} / \mathrm{HC}_{\mathrm{t}}$; human capital efficiency coefficient at $\mathrm{t}$

$\mathbf{S C E}_{\mathbf{t}}=\mathrm{SC}_{\mathrm{t}} / \mathrm{VAt}$; structural capital efficiency coefficient at $\mathrm{t}$

CEE $_{\mathbf{t}}=\mathrm{VA}_{\mathrm{t}} / \mathrm{CE}_{\mathrm{t}} ;$ capital employed efficiency coefficient at $\mathrm{t}$

$\mathbf{V A}_{\mathbf{t}}=\mathrm{OUT}_{\mathrm{t}}-\mathrm{IN}_{\mathrm{t}}=\mathrm{OP}_{\mathrm{t}}+\mathrm{EC}_{\mathrm{t}}+\mathrm{D}_{\mathrm{t}}+\mathrm{A}_{\mathrm{t}}$; VA is the calculation of output $\left(\mathrm{OUT}_{\mathrm{t}}\right)$ calculated from total sales reduced by Input $\left(\mathrm{IN}_{\mathrm{t}}\right)$ calculated from bought-in materials or cost of goods or services sold; or it could be the calculation of operating income $\left(\mathrm{OP}_{\mathrm{t}}\right)$; employee costs $\left(E_{t}\right)$; depreciation $\left(D_{t}\right)$; and amortization $\left(A_{t}\right)$

$\mathbf{H C}_{\mathbf{t}}=$ total salaries and wages at $\mathrm{t}$

$\mathbf{S C}_{\mathbf{t}}=\mathrm{VA}_{\mathrm{t}}-\mathrm{HC}_{\mathrm{t}}$; structural capital at $\mathrm{t}$

$\mathbf{C E}_{\mathbf{t}}=$ book value of the net assets at $\mathrm{t}$

Human Capital Efficiency (HCE). The efficiency of human capital is represented by HCE[7], [8].

Structural Capital Efficiency (SCE). The efficiency of structural capital and relational capital is represented by SCE[7], [8].

Capital Employed Efficiency (CEE). The efficient use of physical and financial capital is represented by CEE[7], [8].

Moderating Variable

Family Ownership (Fam_OWN). According to Pratama and Wibowo[4], family ownership in this research is measured by the proportion of family ownership in the ownership structure of the firm, i.e. the percentage of ownership that are directly owned by the family with cut-off of $\geq 5$ percent.

Dependent Variable 
Firm Performance (Firm_Perf). Same with the research from Pratama and Wibowo[4], the firm performance is measured by using financial performance. The financial performance is measured by ROA (return on assets ratio) and can be calculated by the following equation:

ROA $=$ Profit before tax / Average total assets.

Control Variable

Firm Size (FSize). Firm size is measured by using firm's total assets at year $t$, then calculated the natural logarithm.

Leverage (Lev). Leverage is calculated by dividing long-term liabilities to total assets.

Years (Year). Years are proxied by dummy variables for each year of the research period minus one period.

\section{Regression Model}

This research uses panel data regression model analysis. The hypotheses testing in this research were using two equation models. Model (1) was used to examine the positive relationship between IC and financial performance. Meanwhile, model (2) is used to examine the role of family ownership as the moderating variable that affect the relationship between IC and firm financial performance. The equation models used to test all of the hypotheses in this research are as follows:

Model 1. The Effect of VAIC on Financial Performance

$$
\begin{gathered}
R O A=\beta_{0}+\beta_{1} \text { VAIC }+\beta_{2} \text { FSize }_{t}+\beta_{3} \text { Lev }_{t} \\
+\beta_{4} \text { Year }_{t}+\varepsilon_{t}
\end{gathered}
$$

Model 2. Interaction Model of VAIC and Family Ownership on Financial Performance

$$
\begin{aligned}
& R O A=\beta_{0}+\beta_{1} V A I C+\beta_{2} F a m_{-} O W N+\beta_{3} V A I C \\
& * \text { Fam_OWN }+\beta_{4} \text { FSize }_{t}+\beta_{5} \text { Lev }_{t} \\
&+\beta_{6} \text { Year }_{t}+\varepsilon_{t} \\
& \text { Where: }
\end{aligned}
$$

$\begin{array}{ll}\text { ROA } & =\text { Financial performance } \\ \text { MB } & =\text { Market performance } \\ \text { VAIC } & =\text { Intellectual Capital } \\ \text { Fam_OWN } & =\text { Family Ownership } \\ \text { VAIC*Fam_OWN } & =\text { Moderating variables of the } \\ & \text { family ownership on IC } \\ \text { FSize } & =\text { Firm Size } \\ \text { Lev } & =\text { Leverage } \\ \text { Year } & =\text { Years (Dummy) } \\ \text { ct } & =\text { error term }\end{array}$

\section{RESULTS}

\section{Hypotheses Testing}

The results of Hypothesis 1 testing can be seen in Table 3. The result showed that VAIC has a significant positive impact on ROA or firm financial performance with a coefficient amounted to 0,01854 at a significance level of 5 percent for Indonesia and 0,00211 at a significance level of 10 percent for Philippines. This indicates that if a firm can use its IC more efficiently, it can lead to improved financial performance of the firm. Therefore, hypothesis 1 that states which intellectual capital has positive effect on the firm financial performance of high-technology firms in Indonesia and Philippines is supported.

The result indicates that efficient and effective use of IC will lead the firm to achieve higher financial performance. The result of this research is consistent with previous studies conducted by Pratama and Wibowo[4] which found that intellectual capital is positively related to ROA which is the proxy of firm financial performance.

The results of Hypothesis 2 testing can be seen in Table 3. The results show that there is no moderating effect of family ownership on the positive relationship between IC and firm financial performance. Therefore, this research is not able to provide evidence that family ownership has role in moderating positive relationship between IC and firm financial performance. Therefore, Hypothesis 2, which states that family ownership has a significant positive role in moderating the relationship between intellectual capital and financial performance of high-technology firms in Indonesia and Philippines is not supported. This result is consistent with the result from Pratama and Wibowo[4] which also cannot found the moderating role of family ownership on the relationship between IC and firm financial performance. The failure to support Hypothesis 2 reveals that the alignment effect may not be applicable to all countries. In addition,

\begin{tabular}{|c|c|c|c|c|}
\hline \multirow{5}{*}{ Independent Variable } & \multicolumn{2}{|c|}{$1^{\text {st }}$ order model } & \multicolumn{2}{|c|}{$2^{\text {nd }}$ order model } \\
\hline & \multicolumn{4}{|c|}{ Dependent Variable } \\
\hline & Indonesia & Philippines & Indonesia & Philippines \\
\hline & MI & MI & M2 & M2 \\
\hline & \multicolumn{4}{|c|}{ ROA } \\
\hline Const & $\begin{array}{l}1,33530 \\
(2,74)^{* *}\end{array}$ & $\begin{array}{c}-0,03930 \\
(-0,49)\end{array}$ & $\begin{array}{c}1,409 \\
(2,71)^{* *}\end{array}$ & $\begin{array}{l}-0,001 \\
(-0,02)\end{array}$ \\
\hline VAIC & $\begin{array}{l}0,01854 \\
(3,61)^{* 8}\end{array}$ & $\begin{array}{c}0,00211 \\
1,71^{*}\end{array}$ & $\begin{array}{c}0,019 \\
(3,47)^{* 8}\end{array}$ & $\begin{array}{l}0,00265 \\
(2,67)^{* * *}\end{array}$ \\
\hline Fam_OWN & - & - & $\begin{array}{l}-0,460 \\
(-1,94)\end{array}$ & $\begin{array}{l}-0,055 \\
(-0,27)\end{array}$ \\
\hline VAIC*Fam_OWN & - & - & $\begin{array}{l}-0,001 \\
(-0,15)\end{array}$ & $\begin{array}{l}-0,014 \\
(-0,33)\end{array}$ \\
\hline FSize & $\begin{array}{l}-0,11905 \\
(-2,71)^{* *}\end{array}$ & $\begin{array}{c}0,01366 \\
1,53\end{array}$ & $\begin{array}{c}-0,123 \\
(-2,65)^{* *}\end{array}$ & $\begin{array}{l}0,009 \\
(1,35)\end{array}$ \\
\hline Lev & $\begin{array}{c}-0,04777 \\
(-2,23)\end{array}$ & $\begin{array}{l}-0,25547 \\
(-1,99)^{* *}\end{array}$ & $\begin{array}{l}-0,044 \\
(-1,83)\end{array}$ & $\begin{array}{c}-0,197 \\
(-2,13)^{* *}\end{array}$ \\
\hline Year & Included & Included & Included & Included \\
\hline $\mathrm{R}^{2}$ Within & 0,4844 & 0,1469 & 0,497 & 0,115 \\
\hline $\mathbf{F}$ & 1789,81 & - & 164,95 & - \\
\hline Prob $>$ F & 0,0000 & - & 0,000 & - \\
\hline Wald $X^{2}$ & - & 41,87 & - & 16,19 \\
\hline Prob $>X^{2}$ & - & 0,000 & - & 0,182 \\
\hline
\end{tabular}
previous studies that had found the alignment effect of family ownership, such as those by Anderson and Reeb[12], is conducted mostly in the setting of developed countries, so it may be different in Indonesia and Philippines.

\section{CONCLUSIONS}

The empirical results of this research showed that intellectual capital has a positive effect on firm financial performance, both in Indonesia and Philippines. This indicates that efficient and effective use of intellectual capital will make the firm achieve higher financial performance.

However, this research could not find any evidence to support the moderating role of family ownership on the 
relationship between IC and firm financial performance. It revealed that the alignment effect might not be applicable to all countries.

\section{REFERENCES}

[1] Tjiptohadi Sawarjuwono and Agustine Prihatin Kadir, "Intellectual Capital: Perlakuan, Pengukuran Dan Pelaporan (Sebuah Library Research)," J. Akunt. dan Keuang., vol. 5, no. 1, pp. 35-57, 2003.

[2] P. Nikolaj Bukh, C. Nielsen, P. Gormsen, and J. Mouritsen, "Disclosure of information on intellectual capital in Danish IPO prospectuses," Accounting, Audit. Account. J., vol. 18, no. 6, pp. 713-732, 2005.

[3] J. B. Barney, "Firm Resources and Sustained Competitive Advantage," Journal of Management, vol. 17, no. 1. pp. 99-120, 1991.

[4] B. Cinintya Pratama and H. Wibowo, "Family ownership and Entrenchment Effect on Intellectual Capital Utilization: Research on High-Technology Companies in Indonesia in Facing Asean Economic Community (AEC) ," J. Akunt. dan Investasi, vol. 18, no. 2, pp. 222-230, 2017.

[5] S. Claessens, S. Djankov, and L. H. P. Lang, The separation of ownership and control in East Asian Corporations, vol. 58, no. 1-2. 2000.
[6] R. W. Carney and T. B. Child, "Changes to the ownership and control of East Asian corporations between 1996 and 2008: The primacy of politics," J. financ. econ., vol. 107, no. 2, pp. 494-513, 2013.

[7] A. Pulic, "VAIC TM - an accounting tool for IC management Ante Pulic," Int. J. Technol. Manag., vol. 20, no. 5-8, pp. 702-714, 2000.

[8] A. Pulic, "Intellectual capital - does it create or destroy value?," Meas. Bus. Excell., vol. 8, no. 1, pp. 62-68, 2004.

[9] J. B. Barney, D. J. Ketchen, and M. Wright, "The future of resource-based theory: Revitalization or decline?," J. Manage., vol. 37, no. 5, pp. 12991315, 2011.

[10] R. M. Grant, "Toward a knowledge-based theory of the firm," Strateg. Manag. J., vol. 17, no. 2, pp.109-122,1996.

[11] J. Keenan and M. Aggestam, "Corporate Governance and Intellectual Capital: some conceptualisations," Corp. Gov. An Int. Rev., vol. 9, no. 4, pp. 259-275, 2001.

[12] R. C. Anderson and D. M. Reeb, "Founding-Family Ownership and Firm Performance: Evidence from the S \& P 500," J. Finance, vol. 58, no. 3, pp. 1301-1328, 2003. 